\title{
リハビリティーション施設に関する研究
}

(九州労災病院の場合)

\section{正会員 青木正夫*}

1. 最近,わが国に拉いてもリハビリテーション(Reh) に対する関心が高まりつつあり，それに伴う専門医，各 種療法師の育成は勿論, 施設の整備, 体系化が望玉 れ る。そこで今回は, Reh 施設の研究の手がかりとして, その施設の充奏がトップレベルにある九州労㷋病院にお いて調查した一部を報告する。調查対象はS 39 年 11 月 26 日の入院患者 333 人（一般病棟 307 人, 回復楝 26 人)。尚, 定床数注一般病棟 350 床, 回復棟 50 床。

2. 病院の計画にあたって, 入院期間, 在院期間は心゙ ッドの回転率に関連して, 病院の規模を始め, 管理, 運 営, 性格や付属施設のあり方にも重要な関係をもってい る。従ってここでは，患者の在院期間を中心として，病 院の利用状況考考察してみる。

平均在院日数 85.5 日 (S 39.4 11), 科别では く内> 106.8 日，<神 $>108.8$ 日，<外 $>31.2$ 日，<整 $>143.2$ 日（S39.4〜7)。これを一般の綜合病院と比較すると， <外>は綜合病院のそれに近いが，<整〉，<内>はか なり長い。しかし，〈内>は「珠肺」を主体とする呼吸 器系結核 (27/41) が多いわりには短い。当日の入院患者 構成は＜整 $>177$ 人，<神 $>51$ 人，<外 $>38$ 人，<内> 41 人，<回 $>26$ 人。これらの在院期間は図-10如く で，1年以上のものが約 $25 \% ， 3$ 年以上に及多ものが 10\%を越えている。

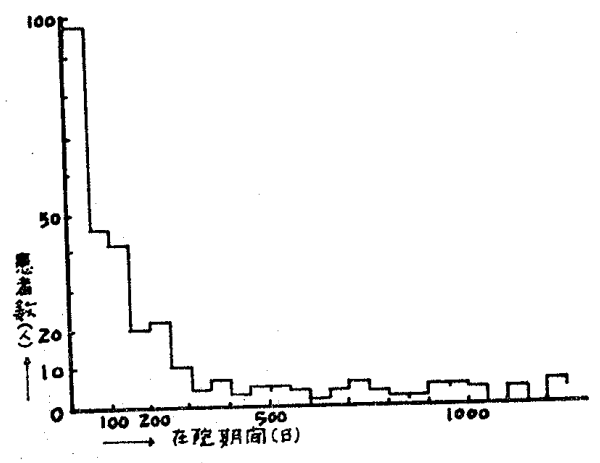

図-1 入院患者の在院期間

3. 病類別に在院期間をみると「I伝染病」「VII神経 系および感覚器の疾患」，「XVII 不慮の事故」の「(1) 頭蓋，脊柱招よび体幹骨折」に長期にわたる患者が多 い。これは「珠肺」,「マヒ・不随」,「春損」の占める 割合が高いためである。「XIII骨および運動器の疾患」, 「XVII 不慮の事故」の「(2)上下肢骨折」および「( 3 ) その他」では在院期間 250 日以上の患者が急減してい
同
$\bigcirc$ 片岡正喜**
同平口
勇***

夻。

4. 専門施設であるReh を有する労荻病院では, この よ5に短期患者と長期患者とが混在している。この点が Reh を整備した病院を計画する際の重要な問題となる。 Reh の専門施設の少ない現在では, 長期に及ぶ「呼吸器 系結核」患者浪療㽰所で, 又「マヒ・不随, 「春損」の 長期にわたる廃人同様の患者は温泉地等に立地する療養 所やそのような患者を専門とする施設（例えば別府の重 度センターで Reh を受療できるようにすべきである う。その結果, Rehの專門施設として十分な機能を発揮 することが可能になると考光られる。

5. Reh の主な治療内容は理学療法 $<\mathrm{P} \cdot \mathrm{T}>$ (一般理 学療法 $<\mathrm{P}>$ 抢上び訓練療法 $<\mathrm{T}>$ ) , 職能療法 $<\mathrm{O}$. T>である。これらのいずれかを受療した患者は，在院 期間 30 日以下のもので約 30\%，30 日以上から 1200 日ぐらいのもので約 60〜70\%，それより長期になると 若干低下寸る。<P>のみの受療は入院当初のものから 在院期間 150 日迄の患者に多く, 150 日以上を越える とほとんどない。く のから長いもにわたってみられるが, 在院期間別の患者 数に対する割合は 300 日以上の「マ, ・不随」「背損」 に高い。 $<\mathrm{P}>$ と $<\mathrm{T}>$ 両方の受療患者は当日の Reh 受療患者の約 40\% を占め, 在院期間 50１50日前後に やや高い。このようにく $\mathrm{P}>と<\mathrm{T}>と$ は密接な関係が あるが，綜合病院が Reh を整備する過程では，まず $<\mathrm{P}>$ に重点を置くべきであらう。

6. $<\mathrm{P} \cdot \mathrm{T}>$ と $<\mathrm{O} \cdot \mathrm{T}>$ とを合わせて受潦している患 者は 50 250 日に偏っている。これは「XVII 不慮の事 故」の「(1) 頭蓋, 脊柱拉よび体幹骨折」の「脊損」以 外と「(2)上下肢骨折」,「( 3 )その他」の患者が在院 期間 250 日者過ぎると急減することに関係し，250日 以前はそれら患者の回復期に当り，積極的に利用される ためである。これと同心゙傾向はく $\mathrm{O} ・ \mathrm{~T}>$ ○牧利用にも 、える。<O・T>の利用は非労災患者惊療できないと いら制約がある。従って全入院患者の約 $20 \%$ が受療し たにとどまり，非労災で高令者の多いく神〉，<内>の 影響も㐫り，長期患者の利用はむしろ少ない。このよう な制約は出来るだけ排除し，他の労災施設や事業主病院 との関倸を密にし, 専問病院としての 滈めることが望まれる。

\footnotetext{
* 九州大学助教授 - 工博 **同講師 *** 同大学院生
} 